\title{
Anti-Oxidative and Anti-Inflammatory Activities of Astragalus membranaceus Fermented by Lactiplantibacillus plantarum on LPS-Induced RAW 264.7 Cells
}

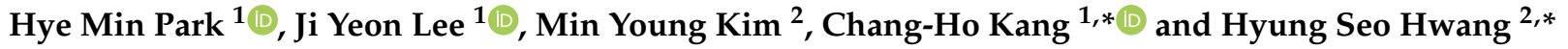 \\ 1 MEDIOGEN, Co., Ltd., Jecheon-si 27159, Korea; hyeminpark95@naver.com (H.M.P.); ljy341@naver.com (J.Y.L.) \\ 2 School of Cosmetic Science and Beauty Biotechnology, Semyung University, Jecheon-si 27136, Korea; \\ alsdud2770@gmail.com \\ * Correspondence: changho-kang@naver.com (C.-H.K.); hshwang@semyung.ac.kr (H.S.H.); \\ Tel.: +82-43-842-1940 (C.-H.K. \& H.S.H.)
}

check for updates

Citation: Park, H.M.; Lee, J.Y.; Kim, M.Y.; Kang, C.-H.; Hwang, H.S. Anti-Oxidative and

Anti-Inflammatory Activities of Astragalus membranaceus Fermented by Lactiplantibacillus plantarum on LPS-Induced RAW 264.7 Cells. Fermentation 2021, 7, 252. https:// doi.org/10.3390/fermentation7040252

Academic Editor: Kurt A. Rosentrater

Received: 12 October 2021

Accepted: 28 October 2021

Published: 1 November 2021

Publisher's Note: MDPI stays neutral with regard to jurisdictional claims in published maps and institutional affiliations.

Copyright: (C) 2021 by the authors Licensee MDPI, Basel, Switzerland. This article is an open access article distributed under the terms and conditions of the Creative Commons Attribution (CC BY) license (https:/ / creativecommons.org/licenses/by/ $4.0 /)$.

\begin{abstract}
Astragalus membranaceus (AM) has been used for anti-oxidative, anti-inflammatory, anticancer, and immunomodulatory activities. In this study, we confirmed that the anti-oxidative and anti-inflammatory effects of AM were enhanced after it was fermented by Lactiplantibacillus plantarum. The anti-oxidative effect was measured by 2,2-Diphenyl-1-picrylhydrazyl (DPPH) radical levels, total phenolic contents (TPC), reducing power, and $\mathrm{H}_{2} \mathrm{O}_{2}$ levels. AM-LP MG5145 and MG5276 showed higher free radical scavenging activity than AM-NF (51.22\%). In addition, AM-LP MG5145 and MG5276 showed higher TPC (49.11 mg GAE/mL), reducing power $\left(\mathrm{OD}_{700}=0.37\right)$, and $\mathrm{H}_{2} \mathrm{O}_{2}(1.71 \mu \mathrm{M})$ than AM-NF. The calycosin contents determined to AM-NF $(17.24 \mathrm{ng} / \mathrm{mL})$, AM-LP MG5145 (139.94 ng/mL), and MG5276 (351.01 ng/mL) using UPLC-ESI-MS/MS. Anti-inflammatory effects were analyzed by investigating the inhibitory effects of fermented AM on cytotoxicity, NO production, and mRNA expression of COX-2, iNOS, NF- $\mathrm{kB}$, and TNF- $\alpha$ in LPS-induced RAW 264.7 cells. AM-LP MG5145 and MG5276 showed no cytotoxicity. AM-LP MG5145 (50.86\%) and MG5276 (51.66\%) inhibited NO production in LPS-induced RAW 264.7 cells. Moreover, AM-LP MG5145 and MG5276 downregulated macrophage iNOS, COX2, TNF- $\alpha$, and NF- $\mathrm{kB}$ expression. In conclusion, A. membranaceus fermented by L. plantarum MG5145 and MG5276 can be used in cosmetics and health foods as natural antioxidant compounds.
\end{abstract}

Keywords: Astragalus membranaceus; Lactiplantibacillus plantarum; anti-oxidant; inflammation; calycosin

\section{Introduction}

Oxidative stress is the most common cause of aging and age-related chronic disease. Radical oxygen species (ROS) including hydrogen peroxide $\left(\mathrm{H}_{2} \mathrm{O}_{2}\right)$ and hydroxyl radicals $(\mathrm{OH}-)$ are important factors in oxidative stress due to their unstable structures and are known to cause cell membrane degradation, lipid oxidation, protein denaturation, and DNA damage [1]. During hyperinflammation, ROS activate c-Jun N-terminal kinases (JNK) and IKB kinase (IKK) to express the nuclear factor $\kappa$-light-chain-enhancer of activated $B$ cells (NF-kB), nitric oxide synthase (iNOS), and prostaglandin-endoperoxide synthase-2 (COX-2) [2]. Inflammation is a non-specific defense mechanism that protects the body from physical and chemical trauma or pathogen attacks. A damaged tissue activates various factors of the immune system to release inflammatory mediators, including cytokines like COX-2, iNOS, and NF- $\mathrm{kB}$, leading to a local inflammatory response [3]. Tumor necrosis factor- $\alpha(\mathrm{TNF}-\alpha)$ is mainly expressed in activated macrophages and is upregulated when stimulated by immunogenic molecules like lipopolysaccharides (LPS). NF- $\mathrm{B}$ activates major factors of oxidation and inflammation, such as pro-inflammatory cytokines, COX-2, iNOS, and nitric oxide (NO) [4]. Prolonged inflammation by these factors can damage normal tissues and develop into chronic inflammation, leading to organ dysfunction syndrome $[5,6]$. 
Astragalus membranaceus (AM) is a perennial herb of the Fabaceae/Leguminosae family whose roots have medicinal properties [7]. It is widely distributed in Asian countries, including China, Japan, Russia, and Korea [8]. AM is rich in polysaccharides, saponins, and isoflavonoids, such as formononetin, calycosin, isomucronulatol 7-O-glucoside, daidzein, and daidzin components $[9,10]$. Isoflavonoids have anti-aging effects-they are antioxidants and skin whiteners and enhance skin elasticity $[9,10]$. With the growth in the health and beauty industries, research on the effectiveness of natural products or herbal medicines has also increased. Although the sprouts of AM are known to have anti-inflammatory, anti-wrinkle and anti-allergic properties, further studies using AM radix for use in health and beauty products is needed [11].

Along with the research on properties of natural products, technology is being used to increase bioconversion efficiency through fermentation using probiotics that can grow on various substrates [12]. Lactobacillus and Bifidobacterium species are generally used as probiotics [13]. Previous studies have reported the anti-oxidative and anti-inflammatory activity of ginseng and ginseng fruit extracts fermented by Lactobacillus sp. [14,15]. Thus, plant fermentation by probiotic strains to enhance the nutritional value of food and improve its taste and aroma is gaining traction in the food and pharmaceutical industries [16,17].

In this study, after fermenting AM using Lactiplantibacillus plantarum (formerly Lactobacillus plantarum) strains isolated from various fermented foods, anti-oxidative and LPS-induced RAW 264.7 cells were used to determine the anti-inflammatory activity of L. plantarum fermented AM extract. In addition, the possibility of its use as a functional food was examined by analyzing the calycosin content using UPLC-ESI-MS/MS.

\section{Materials and Methods}

\subsection{Preparation of Fermentation Sample}

Thirty-seven strains of L. plantarum used in this study were isolated from various fermented foods [18]. The strains were pre-cultured in Man-Rogosa-Sharpe (MRS; Difco, Sparks, MD, USA) broth at $37{ }^{\circ} \mathrm{C}$ for $24 \mathrm{~h}$. AM grown in Jecheon for one year was purchased from the Chungbuk Herb Farming Association (Jecheon-si, Korea) and was used to prepare an aqueous extract. Dried AM $(100 \mathrm{~g})$ was extracted in $2 \mathrm{~L}$ of water at $60^{\circ} \mathrm{C}$ for $15 \mathrm{~h}$. The AM extract was filtered using Whatman No. 2 filter paper (GE Healthcare BioScience, Pittsburgh, PA, USA) and stored at $4{ }^{\circ} \mathrm{C} .1 \%(v / v)$ aqueous filtrates of AM were added to the growth medium containing $2.5 \%$ glucose, $0.5 \%$ peptone, and $1.65 \%$ yeast extract. After autoclaving at $121{ }^{\circ} \mathrm{C}$ for $15 \mathrm{~min}$, Each $2 \%(v / v)$ of L. plantarum $\left(\mathrm{OD}_{600}=1.0\right.$, $10^{8}-10^{9} \mathrm{CFU} / \mathrm{mL}$ ) strains were inoculated into the medium and fermented for $15 \mathrm{~h}$ at $37^{\circ} \mathrm{C}$ (Figure 1). The supernatant was filtered and diluted for use in subsequent experiments.

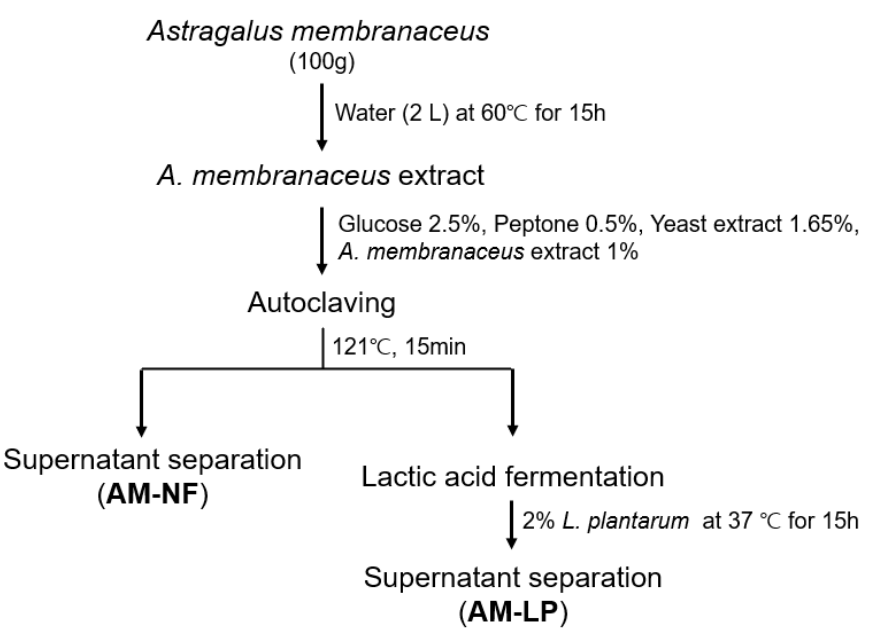

Figure 1. Method for the preparation of A. membranaceus extracts fermented by Lactiplantibacillus plantarum. AM-NF; A. membranaceus extract not fermented by L. plantarum, AM-LP; A. membranaceus extract fermented by L. plantarum. 


\subsection{Anti-Oxidative Activity of A. membranaceus Extract Fermented by L. plantarum (AM-LP)}

\subsubsection{DPPH Radical Scavenging Assay}

The 2,2-diphenyl-1-picrylhydrazyl (DPPH) radical scavenging assay was performed using the modified Blois method [19]. AM-LP samples $(0.2 \mathrm{~mL})$ were mixed with $0.2 \mathrm{mM}$ DPPH (Alfa-Aesar, Karlsruhe, Germany) and 99.5\% methanol (0.3 mL). The mixtures were then left to react in the dark for $10 \mathrm{~min}$. DPPH radical scavenging was measured at $517 \mathrm{~nm}$ using a spectrophotometer (Genesys ${ }^{\mathrm{TM}} 10 \mathrm{~S}$ UV Vis, Thermo Scientific, Waltham, MA, USA). L-ascorbic acid (TCI, Tokyo, Japan) was used as a positive control. The DPPH radical scavenging effect was calculated using the following equation [20]:

$$
\text { DPPH scavenging effect }(\%)=\left[1-\left(\mathrm{OD}_{517} \text { sample } / \mathrm{OD}_{517} \text { control }\right)\right] \times 100
$$

\subsubsection{Total Phenolic Content (TPC) Assay}

The TPC was analyzed using Folin-Ciocalteu's reagent using the modified Cheung method [21]. The AM-LP samples were diluted in a 1:10 ratio with distilled water, and $0.1 \mathrm{~mL}$ of the diluted samples were mixed with $0.05 \mathrm{~mL}$ of $1 \mathrm{~N}$ Folin-Ciocalteu reagent (Sigma Aldrich, St. Louis, MO, USA) and $0.4 \mathrm{~mL}$ of distilled water. After $3 \mathrm{~min}, 0.1 \mathrm{~mL}$ of $20 \%$ sodium carbonate anhydrous solution and $0.35 \mathrm{~mL}$ distilled water were added, and the mixtures were incubated for $1 \mathrm{~h}$ at room temperature. The reaction solutions were centrifuged at 15,000 rpm for $10 \mathrm{~min}$, and the absorbance was measured at $725 \mathrm{~nm}$ using a multi-plate reader (EPOCH2, Biotek, Winooski, VT, USA). TPC was expressed as mg/mL gallic acid equivalent (GAE) units based on a standard curve $(\mathrm{Y}=0.0058 \mathrm{X}+0.0165)$.

\subsubsection{Reducing Power Assay}

Reducing power is a method for evaluating anti-oxidative potential using absorbance value. When an antioxidant is present in the sample, the ferric-ferricyanide $\left(\mathrm{Fe}^{3+}\right)$ mixture stabilizes the free radicals by donating hydrogen, and the reducing power converting $\mathrm{Fe}^{3+}$ to $\mathrm{Fe}^{2+}$ is expressed as absorbance [22]. The reducing power was determined using the modified Oyaizu method [23]. The AM-LP samples were diluted (1:10) with distilled water. $250 \mu \mathrm{L}$ of the diluted samples mixed with $250 \mu \mathrm{L}$ of $0.2 \mathrm{M}$ phosphate buffer and $250 \mu \mathrm{L}$ of $1 \%$ potassium ferricyanide (Daejung, Gyeonggi-do, Korea). The mixtures were incubated at $50{ }^{\circ} \mathrm{C}$ for $20 \mathrm{~min}$. Next, $250 \mu \mathrm{L}$ of $10 \%$ trichloroacetic acid (Sigma Aldrich) was added, and the mixtures were centrifuged at $3000 \mathrm{rpm}$ for $10 \mathrm{~min}$. Then, $500 \mu \mathrm{L}$ of each supernatant was mixed with $500 \mu \mathrm{L}$ of distilled water and $100 \mu \mathrm{L}$ of $0.1 \%$ iron (III) chloride hexahydrate (Daejung) solution. The absorbance was measured at $700 \mathrm{~nm}$ using a microplate reader (Biotek). L-ascorbic acid was used as a positive control.

\subsubsection{Hydrogen Peroxide $\left(\mathrm{H}_{2} \mathrm{O}_{2}\right)$ Content Assay}

AM-LP samples were diluted (1:10) with a $1 \mathrm{X}$ reaction buffer and analyzed using the EZ-hydrogen peroxide/peroxidase assay kit (DoGen Bio, Seoul, Korea). Diluted samples $(50 \mu \mathrm{L})$ were mixed with $50 \mu \mathrm{L}$ Oxi-Probe/HRP Working Solution in a 96-well plate and then incubated in the dark for $30 \mathrm{~min}$. The absorbance was measured at $560 \mathrm{~nm}$ using a microplate reader (Biotek). $\mathrm{H}_{2} \mathrm{O}_{2}$ solution $(10 \mu \mathrm{M})$ used a positive control and $1 \mathrm{X}$ reaction buffer used a negative control.

\subsection{UPLC-ESI-MS/MS Analysis}

\subsubsection{Preparation of Sample and Standard Solution}

Calycosin was purchased from Sigma-Aldrich. The compounds were dissolved in 100\% ethanol (HPLC grade) to prepare 100 ppm stock solutions. All prepared stock solutions were filtered through a PTFE $0.45 \mu \mathrm{m}$ syringe filter (ADVANTEC, Tokyo, Japan), stored at $4{ }^{\circ} \mathrm{C}$, and diluted before analysis. 


\subsubsection{Conditions of Analysis}

The compound was analyzed by ultra-performance liquid chromatography (UPLC; NEXERA G2, Shimadzu, Kyoto, Japan). A. membranaceus extract not fermented by L. plantarum (AM-NF) and AM-LP samples were filtered through a $0.22 \mu \mathrm{m}$ membrane filter (ADVANTEC, Tokyo, Japan) and analyzed (Table 1). For analysis, Zorbax Eclipse Plus C18 column $(100 \mathrm{~mm} \times 4.6 \mathrm{~mm}, 3.5 \mu \mathrm{m}$; Agilent Technologies, Santa Clara, CA, USA) and $0.1 \%$ formic acid in water (A) and $0.1 \%$ formic acid in acetonitrile (B) as mobile phases using a linear gradient were used. The column temperature was maintained at $25^{\circ} \mathrm{C}$. The flow rate was $0.7 \mathrm{~mL} / \mathrm{min}$, and the injection volume was $5 \mu \mathrm{L}$. All mobile phases used in the analysis were HPLC grade and were purchased from Duksan (Gyeonggi-do, Korea). For mass analysis, an API 3200 QTRAP mass spectrometer (Applied Biosystem, Waltham, CA, USA) with an electrospray ionization (ESI) source operated in the positive ion mode with selected ion monitoring (SIM) (Table S1).

Table 1. The ultra-performance liquid chromatography with electrospray ionization mass spectrometer (UPLC-ESI-MS/MS) conditions for calycosin analysis.

\begin{tabular}{|c|c|c|c|}
\hline Instruments & \multicolumn{3}{|c|}{ NEXERA G2 (Shimadzu, Kyoto, Japan) } \\
\hline Column & \multicolumn{3}{|c|}{$\begin{array}{l}\text { Zorbax Eclipse Plus C18 column } \\
(100 \mathrm{~mm} \times 4.6 \mathrm{~mm}, 3.5 \mu \mathrm{m})\end{array}$} \\
\hline Column temperature & \multicolumn{3}{|c|}{$25^{\circ} \mathrm{C}$} \\
\hline Flow rate & \multicolumn{3}{|c|}{$0.7 \mathrm{~mL} / \mathrm{min}$} \\
\hline Injection volume & \multicolumn{3}{|c|}{$5.0 \mu \mathrm{L}$} \\
\hline Mohil nhase & \multirow{2}{*}{\multicolumn{3}{|c|}{$\begin{array}{l}\text { A: } 0.1 \% \text { formic acid in water } \\
\text { B: } 0.1 \% \text { formic acid in acetonitrile }\end{array}$}} \\
\hline Viobil phase & & & \\
\hline \multirow{7}{*}{$\begin{array}{l}\text { Gradient } \\
\text { Conditions }\end{array}$} & Time (min) & Solvent A (\%) & Solvent B (\%) \\
\hline & 0 & 80 & 20 \\
\hline & 2 & 80 & 20 \\
\hline & 12 & 5 & 95 \\
\hline & 14 & 5 & 95 \\
\hline & 18 & 80 & 20 \\
\hline & 20 & 80 & 20 \\
\hline Mass spectrometer equipped & \multicolumn{3}{|c|}{$\begin{array}{c}\text { API3200QTRAP } \\
\text { (Applied Biosystem, CA, USA) }\end{array}$} \\
\hline Ion sprey voltage (ISV): $5200 \mathrm{~V}$ & \multicolumn{3}{|c|}{ GS1: 40 psi } \\
\hline Curtain gas: 10 psi & \multicolumn{3}{|c|}{ GS2: 40 psi } \\
\hline CAD gas: medium & \multicolumn{3}{|c|}{ Capillary temperature: $500{ }^{\circ} \mathrm{C}$} \\
\hline
\end{tabular}

\subsection{Cell Culture}

RAW 264.7 cells were obtained from the Korea Cell Line Bank (Seoul, South Korea) and grown in Dulbecco's modified Eagle's medium (DMEM; Welgene, Gyeongsangbuk-do, Korea) supplemented with $10 \%$ fetal bovine serum (FBS; Welgene), $100 \mathrm{unit} / \mathrm{mL}$ penicillin, and $100 \mu \mathrm{g} / \mathrm{mL}$ streptomycin (Gibco, Grand Island, NY, USA) at $37^{\circ} \mathrm{C}$ in $5 \% \mathrm{CO}_{2}$ in fully humidified air. The cells were sub-cultured every 2-3 days at a confluence of $80-95 \%$.

\subsection{Cell Viability}

Cell Counting kit-8 (CCK-8; DoGen Bio) was used to determine cytotoxicity. Cells were seeded into 24 -well plates at a density of $2.0 \times 10^{5}$ cells /well and stabilized for $24 \mathrm{~h}$. AM $(500 \mu \mathrm{L})$ fermented by L. plantarum MG5145 (AM-LP MG5145) and L. plantarum MG5276 (AM-LP MG5276) with or without LPS $(0.5 \mu \mathrm{g} / \mathrm{mL})$ in phenol red-free DMEM medium was added to each well for $24 \mathrm{~h}$. The phenol red-free DMEM and CCK-8 solutions were mixed at a ratio of $10: 1$. Then, $100 \mu \mathrm{L}$ was dispensed into each well and incubated at $37^{\circ} \mathrm{C}$ for $30 \mathrm{~min}$. The absorbance was measured at $450 \mathrm{~nm}$ using a microplate reader (Biotek). 


\subsection{Anti-Inflammatory Activity of AM-LP}

\subsubsection{Determination of NO Production}

NO production was measured using the Griess assay [24]. RAW 264.7 cells were cultured on 24-well plates at a density of $2.0 \times 10^{5}$ cells/well and stabilized for $24 \mathrm{~h}$. AM $(500 \mu \mathrm{L})$ fermented by L. plantarum MG5145 (AM-LP MG5145) and L. plantarum MG5276 (AM-LP MG5276) with or without LPS $(0.5 \mu \mathrm{g} / \mathrm{mL})$ in phenol red-free DMEM was added to each well for $24 \mathrm{~h}$. Then, $40 \mathrm{mg} / \mathrm{mL}$ of Griess (G4410, Sigma Aldrich, St. Louis, $\mathrm{MO}, \mathrm{USA}$ ) solution was added to each well and mixed at a ratio of 1: 1 at room temperature for $30 \mathrm{~min}$. The absorbance was measured at $540 \mathrm{~nm}$ using a microplate reader (Biotek). NO production was calculated using a standard curve $(Y=0.0058 \mathrm{X}+0.0165)$ prepared using sodium nitrate (range; $0-100 \mu \mathrm{M}$ ).

\subsection{2. mRNA Extraction and Quantitative Real Time-PCR}

Cells were seeded in 6-well plates at a density of $5.0 \times 10^{5}$ cells/well and cultured at $37^{\circ} \mathrm{C}$ for $24 \mathrm{~h}$. To confirm the expression-related inflammation, total RNA was extracted with TRIzol reagent (Ambion, Foster City, CA, USA) after treatment with LPS $(0.5 \mu \mathrm{g} / \mathrm{mL})$ for $6 \mathrm{~h}$ from each AM-LP treated group. Total RNA $(1.5 \mu \mathrm{g})$ was used to synthesize cDNA by reverse transcription with Revertra Ace Kit. cDNA $(5 \mu \mathrm{L})$ was mixed with $4 \mu \mathrm{L}$ of DEPC-water (Sigma Aldrich), $10 \mu \mathrm{L}$ of Master MIX (Applied Biosystems, Waltham, CA, USA), and $1 \mu \mathrm{L}$ of TaqMan probe (Thermo Scientific). mRNA levels were analyzed by gene amplification using qPCR (Applied Biosystems). The TaqMan probes used are shown in Table 2.

Table 2. Gene name and assay ID number in qPCR analysis.

\begin{tabular}{ccc}
\hline Symbol & Gene Name & Assay ID \\
\hline GAPDH & Glyceraldehyde-3-phosphate dehydrogenase & Mm99999915_g1 \\
TNF- $\alpha$ & Tumor necrosis factor alpha & Mm00443258_m1 \\
iNOS & Inducible nitic oxide synthase & Mm00440502_m1 \\
COX-2 & Cyclooxygenase-2 & Mm00478374_m1 \\
NF- $\mathrm{KB}$ & Nuclear factor kappa-light-chain-enhancer of & Mm00476361_m1 \\
& activated B cells & \\
\hline
\end{tabular}

\subsection{Statistical Analysis}

The data was analyzed using Student's t-test and one-way analysis of variance (ANOVA) using Tukey's multiple comparison test (GraphPad Prism version 5.02). The results of this study are presented as mean \pm standard deviation (SD).

\section{Results \& Discussion}

\subsection{Anti-Oxidative Activity of AM-NF and AM-LP}

The DPPH assay is a widely used, relatively quick method for evaluating free radical scavenging activity [25]. Thus, the anti-oxidative activity of the 37 strains (Table S2) determined using DPPH assay. AM-NF had a radical scavenging ability of $51.22 \pm 1.49 \%$ in its undiluted form with L-ascorbic acid as a positive control. It showed a high radical scavenging ability of $85.67 \pm 1.15 \%$ at a concentration of $100 \mu \mathrm{g} / \mathrm{mL}$. The radical scavenging ability of AM-LP fermented by various L. plantarum strains was measured in the range of $48.66 \pm 0.74$ to $72.05 \pm 0.60 \%$ in its undiluted form. The radical scavenging ability of AM extracts fermented using L. plantarum MG5145 and L. plantarum MG5276 strains were significantly higher $(72.05 \pm 0.60$ and $70.38 \pm 1.12 \%$, respectively).

These results are similar to that of the previous study on the anti-oxidative activity of Houttuynia cordata Thunb. fermented by lactic acid bacteria [26]. Our subsequent experiments measured the anti-oxidative and anti-inflammatory effects of AM-LP MG5145 and MG5276 that had high anti-oxidative activities.

TPC of AM-NF was $49.11 \pm 0.87 \mathrm{mg} \mathrm{GAE} / \mathrm{mL}$; however, it increased significantly after L. plantarum fermentation. TPC of AM-LP MG5145 was the highest at $53.30 \pm 0.72 \mathrm{mg} \mathrm{GAE} / \mathrm{mL}$, 
followed by AM-LP MG5276 at $49.17 \pm 1.27 \mathrm{mg} \mathrm{GAE} / \mathrm{mL}$ (Figure 2a). The reducing power was assayed with ascorbic acid $(20 \mu \mathrm{g} / \mathrm{mL})$ as a positive control (absorbance; $0.44 \pm 0.00)$ and found the absorbance of AM-NF to be $0.37 \pm 0.00$, while those of AM-LP MG5145 and AM-LP MG5276 were $0.39 \pm 0.00$ and $0.41 \pm 0.00$, respectively (Figure $2 \mathrm{~b}$ ). $\mathrm{H}_{2} \mathrm{O}_{2}$ is a ROS that produces lipid peroxide and causes cell damage [1]. Therefore, to confirm ROS scavenging by AM-LP, the $\mathrm{H}_{2} \mathrm{O}_{2}$ content in the medium was measured (Figure $2 \mathrm{c}$ ). AM-LP MG5145 $\mathrm{H}_{2} \mathrm{O}_{2}$ content was $1.98 \pm 0.08 \mu \mathrm{M}$, similar to AM-NF $(1.71 \pm 0.11 \mu \mathrm{M})$, but AM-LP MG5276 had significantly decreased $\mathrm{H}_{2} \mathrm{O}_{2}$ content at $0.58 \pm 0.17 \mu \mathrm{M}$ after fermentation.

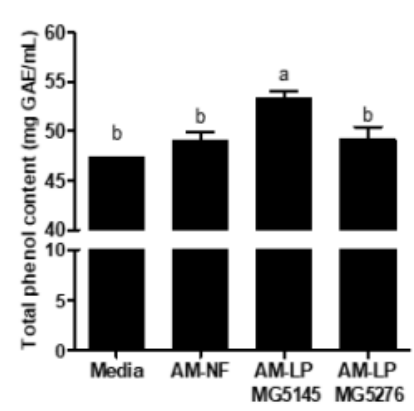

(a)

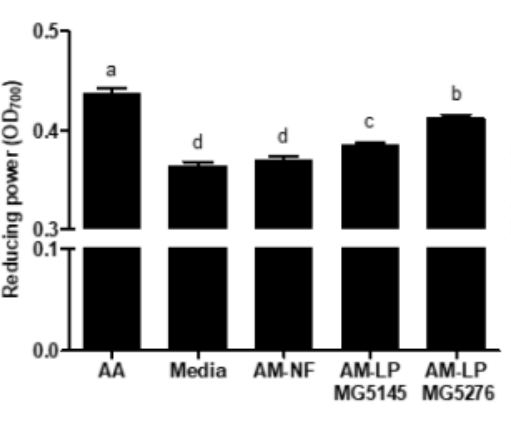

(b)

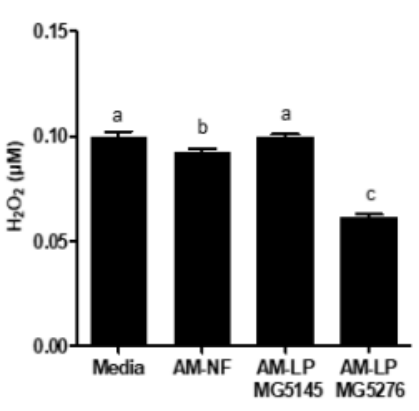

(c)

Figure 2. (a) Total phenol content (TPC) (b) reducing power, and (c) total $\mathrm{H}_{2} \mathrm{O}_{2}$ content of AM-NF, AM-LP MG5145, and MG5276. Values are expressed as means \pm SD $(n=3)$. Means with different letters within a column are significantly different at $p<0.05$ using Tukey's multiple comparison test. Media: media without A. membranaceus extract, AA: ascorbic acid, AM-NF: A. membranaceus extract not fermented by L. plantarum, AM-LP: A. membranaceus extract fermented by L. plantarum.

Fermentation using probiotics increases anti-oxidative activity by increasing the phenolic compounds in Houttuynia cordata and Panax ginseng [14,26]. In addition, AM leaf extracts fermented with probiotics have increased anti-oxidative activity [27], proving that fermentation by probiotic microbes, especially L. plantarum, increases the anti-oxidative activity of AM.

\subsection{Method Validation of Calycosin for AM-NF and AM-LP Analysis by UPLC}

The calycosin analysis was validated for AM-NF and AM-LP using UPLC by measuring the linearity with at least five concentrations and ensuring that the coefficient of determination was 0.99 or higher after creating a calibration curve with the area of the analyzed active ingredient [28]. Furthermore, it should be confirmed this through the Y-intercept and the slope of the regression line [28] (Table 3).

Table 3. Calibration curves for determining the LOD and LOQ values of standards $(n=3)$.

\begin{tabular}{|c|c|c|c|c|}
\hline Standards & Calibration Curve ${ }^{(1)}$ & $\mathbf{R}^{(2)}$ & $\begin{array}{l}\operatorname{LOD}^{(3)} \\
(\mathrm{ng} / \mathrm{mL})\end{array}$ & $\begin{array}{l}\operatorname{LOQ}^{(4)} \\
(\mathrm{ng} / \mathrm{mL})\end{array}$ \\
\hline Calycosin & $Y=606.15 X+50564$ & 1.00 & 169.97 & 1.94 \\
\hline
\end{tabular}

A calibration curve was created from the peak areas analyzed using UPLC-ESIMS/MS for calycosin. The coefficient of determination was 0.995 , indicating good linearity $(Y=606.15 X+50564)$ for quantitative analysis. In addition, the LOD and LOQ were $169.97 \mathrm{ng} / \mathrm{mL}$ and $1.94 \mathrm{ng} / \mathrm{mL}$.

\subsection{Analysis of Calycosin in AM-NF and AM-LP Using UPLC-ESI-MS/MS}

Calycosin is a flavonoid with strong anti-oxidative properties that helps eliminate oxidative stress caused by free radicals and ROS [29]. Therefore, calycosin from AM extracts 
was analyzed before and after fermentation using UPLC-ESI-MS/MS. Mass spectrometry of the calycosin ion peaks $[\mathrm{M}+\mathrm{H}+\mathrm{Na}]^{+}$was confirmed at $\mathrm{m} / \mathrm{z} 307.1$, and retention time was observed as $6.6 \mathrm{~min}$ (Figure 3 and Figure S1). Quantitative analysis of calycosin was performed using a standard curve (Table 3). The calycosin content of AM-NF was $17.24 \pm 0.11 \mathrm{ng} / \mathrm{mL}$. After fermentation by L. plantarum MG5145 and MG5276, the calycosin content increased to $139.94 \pm 0.23$ and $351.01 \pm 0.29 \mathrm{ng} / \mathrm{mL}$, respectively (Figure 3 and Table 4).

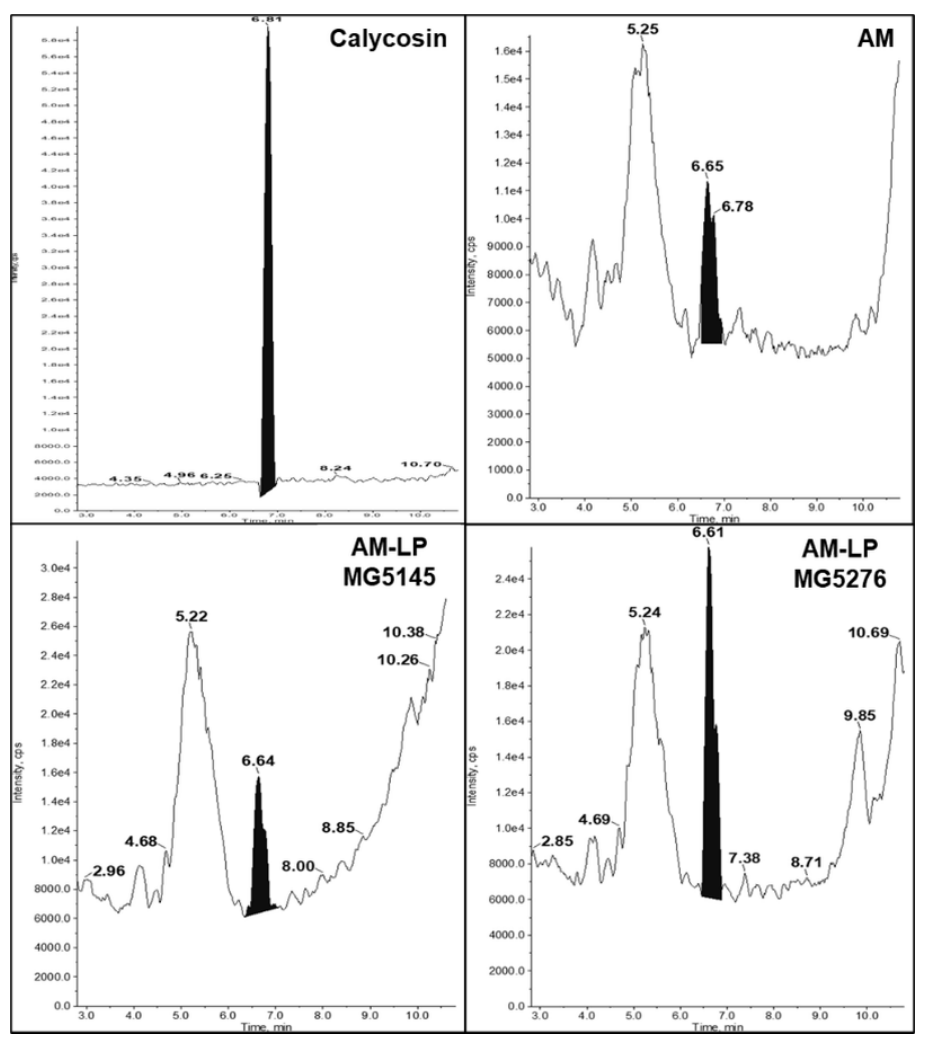

Figure 3. The chromatograms of calycosin (standard; $100 \mathrm{ppm}$ ). Each sample was analyzed using UPLC-ESI-MS/MS. The black peak on each chromatogram indicates the standard.

Table 4. The ultra-performance liquid chromatography ionization-mass spectrometry of calycosin (UPLC-ESI-MS/MS).

\begin{tabular}{cccc}
\hline \multirow{2}{*}{ Standard } & \multicolumn{3}{c}{ Calculated Concentration (ng/mL) } \\
\cline { 2 - 4 } & AM-NF & AM-LP MG5145 & AM-LP MG5276 \\
\hline Calycosin & $17.24 \pm 0.11$ & $139.94 \pm 0.23$ & $351.01 \pm 0.29$ \\
\hline Values are expressed as mean \pm SD. & &
\end{tabular}

Values are expressed as mean \pm SD.

Previous studies have reported that AM inhibits free radicals, reduces lipid peroxidation, and increases anti-oxidative enzymes [30]. Among the compounds present in AM, calycosin is known to have anti-oxidative and anti-inflammatory effects [31]. Sugar is decomposed during the fermentation of natural products, and the decomposition product is more bioactive [27]. In this study, L. plantarum MG5145 and MG5276 enhanced the calycosin content through fermentation. Therefore, the beneficial activity of AM-LP MG5145 and MG5276 appears to be due to an increase in calycosin content. 


\subsection{Viability of AM-LP in LPS-Induced RAW 264.7 Cells}

The CCK-8 cytotoxicity test was performed on the $20 \%(v / v)$ AM extracts before and after L. plantarum fermentation in RAW 264.7 cells. Fermented extracts AM-LP MG5145 $(101.57 \pm 0.63 \%)$ and MG5276 (101.26 $\pm 3.20 \%)$ were not cytotoxic (Figure 4a).

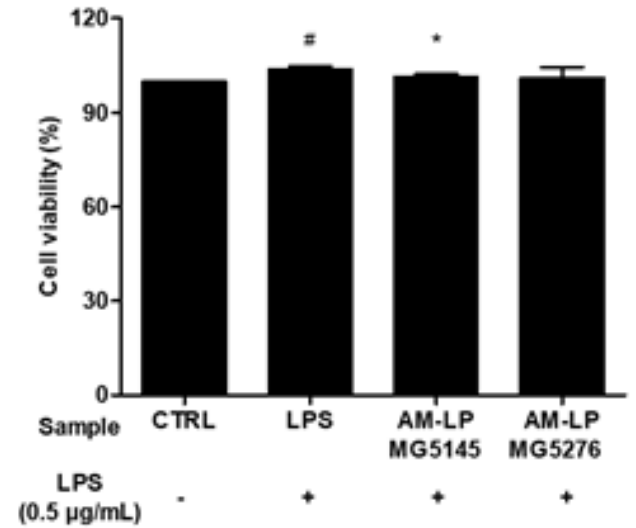

(a)

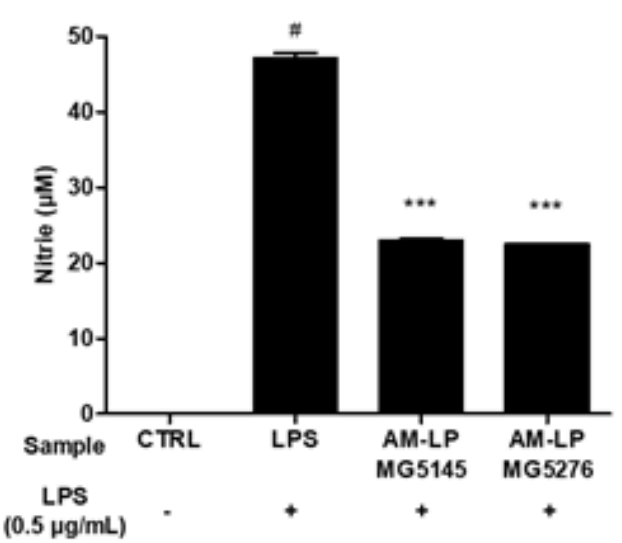

(b)

Figure 4. Effect of AM-LP MG5145 and AM-LP MG5276 on (a) Cell viability and (b) NO production in LPS-induced RAW 264.7 cells. Cells were treated with $20 \%(v / v)$ samples and LPS $(0.5 \mu \mathrm{g} / \mathrm{mL})$ for $24 \mathrm{~h}$. Data are represented as the mean $\pm \operatorname{SD}(n=3) .{ }^{*} p<0.05$ compared to untreated LPS control. ${ }^{*} p<0.05$ and ${ }^{* * *} p<0.001$ compared to treated LPS control.

$\mathrm{NO}$ is important in inflammatory responses [32]. NO production was confirmed using LPS-induced RAW 264.7 cells (Figure 4b). The NO production in RAW 264.7 cells treated with LPS was markedly increased to $47.48 \pm 0.39 \mu \mathrm{M}$. The AM-LP MG5145 and MG5276 inhibited NO production, decreasing its concentration to $23.33 \pm 0.44 \mu \mathrm{M}$ and $22.96 \pm 0.29 \mu \mathrm{M}$, respectively. It was confirmed that the inhibitory effect of AM-LP MG5145 and MG5276 on NO production was not due to their cytotoxicity.

$\mathrm{NO}$, a free radical produced by cNOS and iNOS, induces oxidative injury in several biological systems [33,34]. Both AM-LP MG5145 and MG5276 reduced NO production in LPS-induced RAW 264.7 cells. In addition, calycosin inhibits MAPK phosphorylation, NF$\kappa \mathrm{B}$ activation, and NO production $[35,36]$. Therefore, it was confirmed that calycosin-rich AM-LP MG5145 and MG5276 significantly reduced NO production.

\subsection{AM-LP Inhibits TNF- $\alpha$, iNOS, COX-2, NF- $\kappa B$ Levels in LPS-Induced RAW 264.7 Cells}

Since AM-LP MG5145 and MG5276 had a strong inhibitory effect on NO production, The expression of TNF- $\alpha$, iNOS, COX-2, and NF-kB in RAW 264.7 cells stimulated with LPS was examined.

TNF- $\alpha$, an inflammatory cytokine, is produced in large quantities in activated macrophages. LPS increases its production, promoting an inflammatory response [37]. In this study, LPStreated RAW 264.7 cells showed upregulated TNF- $\alpha$ levels (Figure 5a). Treatment with AM-LP MG5145 and MG5276 significantly decreased the mRNA levels of TNF- $\alpha$ by $47.29 \pm 1.06 \%$ and $46.85 \pm 8.95 \%$, respectively, compared with that in the LPS-treated group. In addition, LPS-treated RAW 264.7 cells had increased expression levels of iNOS and COX-2 (Figure $5 b, c)$. However, iNOS expression was reduced by $99.84 \pm 0.06$ and $99.16 \pm 0.01 \%$ and COX-2 by $55.70 \pm 5.46$ and $44.29 \pm 9.91 \%$ in AM-LP MG5145- and MG5276-treated cells, respectively, compared with that in the LPS-treated group. NF- $\mathrm{kB}$, a transcription factor, upregulates pro-inflammatory cytokines [4]. The effect of AM-NF, AM-LP MG5145, and AM-LP MG5276 on NF-KB expression was also analyzed (Figure 5d). When LPS-induced RAW 264.7 cells were treated with AM-LP MG5145 and MG5276, the mRNA expression levels of NF- $\mathrm{kB}$ were significantly reduced by $67.85 \pm 0.80$ and $56.84 \pm 5.27 \%$, respectively, compared with that in the LPS treatment group. 


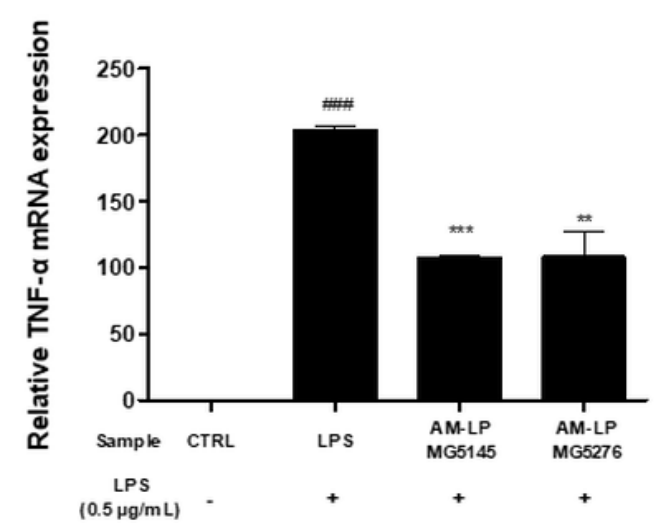

(a)

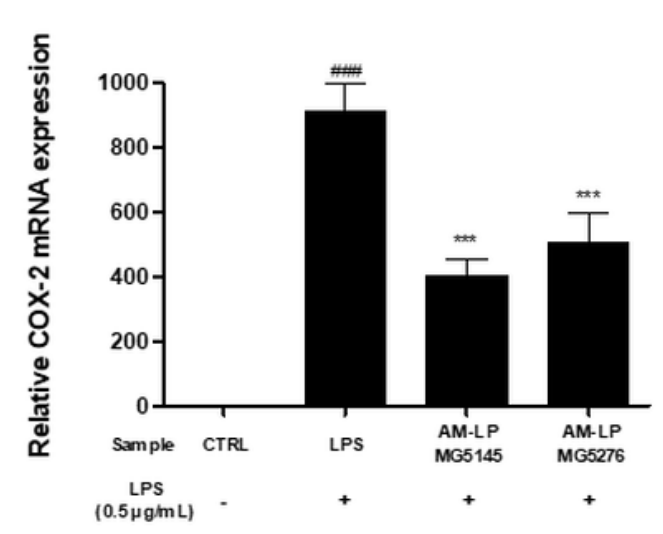

(c)

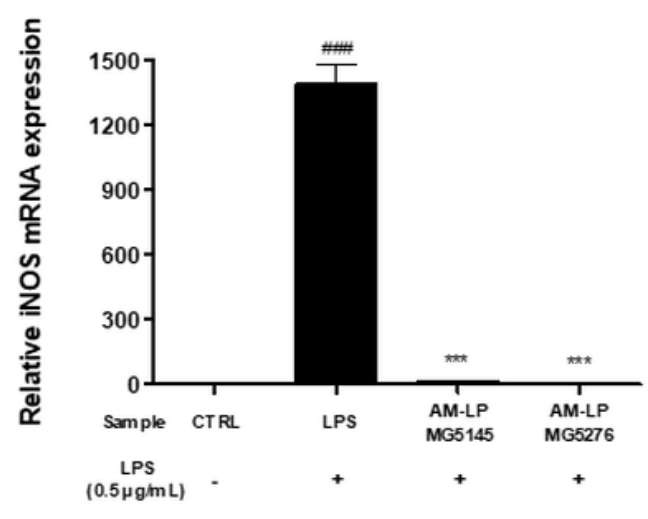

(b)

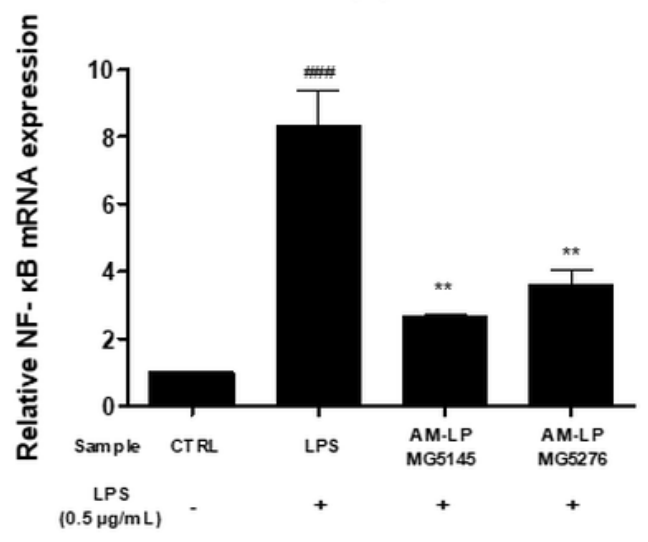

(d)

Figure 5. Effect of the AM-LP MG5145 and MG5276 on inflammation-related mRNA production in LPS-induced RAW 264.7 cells. Cells were treated with samples $(20 \% v / v)$ and LPS $(0.5 \mu \mathrm{g} / \mathrm{mL})$ for $6 \mathrm{~h}$. The expressions of (a) TNF- $\alpha$, (b) iNOS, (c) COX-2, and (d) NF- $\mathrm{kB}$ were measured by qPCR. Data are represented as the mean $\pm \mathrm{SD}(n=3)$. All data were normalized by GAPDH. ${ }^{\# \# \#} p<0.001$ compared to untreated LPS control. ${ }^{* *} p<0.01$ and ${ }^{* * *} p<0.001$ comparing treated LPS control.

In conclusion, AM-LP MG5145 and AM-LP MG5276 significantly reduced the expression levels of TNF- $\alpha$, iNOS, COX-2, and NF-KB in LPS-induced RAW 264.7 cells.

The results of this study suggest that AM-LP MG5145 and AM-LP MG5276 hydrolyze the sugar of isoflavonoid glycoside through bioconversion to increase calycosin content, thereby exhibiting anti-inflammatory activity and anti-oxidative activity.

\section{Conclusions}

In this study, the anti-oxidative and anti-inflammatory effects of AM extracts fermented using L. plantarum strain were investigated. AM-LP MG5145 and MG5276 reduced DPPH radical and $\mathrm{H}_{2} \mathrm{O}_{2}$ content and increased TPC and reducing power compared to AM-NF. Additionally, increased calycosin content in AM-LP MG5145 and MG5276 were observed. The anti-inflammatory effects of AM-LP MG5145 and MG5276 significantly inhibited NO production and suppressed the expression of TNF- $\alpha$, iNOS, COX-2, and NF$\kappa B$. Consequently, fermentation-enhanced AM extracts can be used as novel and effective natural products to enhance the anti-oxidative effect and suppress inflammatory reactions.

Supplementary Materials: The following are available online at https:/ / www.mdpi.com/article/ 10.3390 / fermentation7040252/s1, Figure S1. ESI-MS/MS spectrum of calycosin; Table S1. Selected ion monitoring (SIM) conditions for standards; Table S2. DPPH radical scavenging activities of the AM-NF and AM-LP. 
Author Contributions: Conceptualization, H.S.H. and C.-H.K.; methodology, J.Y.L. and M.Y.K.; formal analysis, H.M.P. and M.Y.K.; investigation, H.M.P. and M.Y.K.; resources, C.-H.K.; data curation, J.Y.L.; writing—original draft preparation, H.M.P.; writing—review and editing, J.Y.L.; visualization, H.M.P., J.Y.L. and M.Y.K.; supervision, H.S.H. and C.-H.K.; project administration, C.-H.K. All authors have read and agreed to the published version of the manuscript.

Funding: This research received no external funding.

Institutional Review Board Statement: Not applicable.

Informed Consent Statement: Not applicable.

Data Availability Statement: Not applicable.

Acknowledgments: This research was supported by the Encouragement program for the healthcare natural products industry (Jecheon-si, Chungcheongbuk-do). This paper was published in Master's degree thesis (Semyung University, Jecheon-si, Chungcheongbuk-do) in August 2021 [38].

Conflicts of Interest: The authors declare no conflict of interest.

\section{References}

1. Rhee, S.G.; Bae, Y.S.; Lee, S.-R.; Kwon, J. Hydrogen peroxide: A key messenger that modulates protein phosphorylation through cysteine oxidation. Sci. Signal. 2000, 2000, pe1. [CrossRef] [PubMed]

2. Guha, M.; Mackman, N. LPS induction of gene expression in human monocytes. Cell. Signal. 2001, 13, 85-94. [CrossRef]

3. Koh, T.J.; DiPietro, L.A. Inflammation and wound healing: The role of the macrophage. Expert Rev. Mol. Med. 2011, 13, E23. [CrossRef] [PubMed]

4. Tak, P.P.; Firestein, G.S. NF-kB: A key role in inflammatory diseases. J. Clin. Investig. 2001, 107, 7-11. [CrossRef]

5. Sorci-Thomas, M.G.; Thomas, M.J. Microdomains, inflammation, and atherosclerosis. Circ. Res. 2016, 118, 679-691. [CrossRef]

6. Hu, H.; Jiang, H.; Ren, H.; Hu, X.; Wang, X.; Han, C. AGEs and chronic subclinical inflammation in diabetes: Disorders of immune system. Diabetes Metab. Res. 2015, 31, 127-137. [CrossRef]

7. Lee, K.-J.; Park, M.-H.; Park, Y.-H.; Lim, S.-H.; Kim, K.-H.; Kim, Y.-G.; Ahn, Y.-S.; Kim, H.-Y. Antioxidant activity and nitric oxide production of ethanol extracts from Astragali membranaceus Bunge and A. membranaceus Bunge var mongholicus Hisiao. Korean J. Food Nutr. 2011, 40, 1793-1796. [CrossRef]

8. Li, Z.X.; Zhao, G.D.; Xiong, W.; Linghu, K.G.; Ma, Q.S.; San Cheang, W.; Yu, H.; Wang, Y. Immunomodulatory effects of a new whole ingredients extract from Astragalus: A combined evaluation on chemistry and pharmacology. Chin. Med. 2019, 14, 12. [CrossRef]

9. Kim, M.J.; Lim, K.R.; Jung, T.K.; Yoon, K.-S. Anti-aging effect of Astragalus membranaceus root extract. J. Soc. Cosmet. Sci. Korea 2007, 33, 33-40.

10. Kim, M.-J.; Kim, J.-Y.; Jung, T.-K.; Choi, S.-W.; Yoon, K.-S. Skin anti-aging effect of Forsythia viridissima L. extract. KSBB J. 2006, 21, $444-450$.

11. Jung, S. Cosmetic Application of Sprouts of Scutellaria baicalensis and Astragalus membranaceus. Ph.D. Thesis, Kyung Hee University, Seoul, Korea, 2018.

12. Bae, E.-A.; Han, M.J.; Kim, E.-J.; Kim, D.-H. Transformation of ginseng saponins to ginsenoside Rh 2 by acids and human intestinal bacteria and biological activities of their transformants. Arch. Pharm. Res. 2004, 27, 61-67. [CrossRef]

13. Tannock, G.W. Probiotic properties of lactic-acid bacteria: Plenty of scope for fundamental R \& D. Trends Biotechnol. 1997, 15, 270-274.

14. Jeon, J.-M.; Choi, S.-K.; Kim, Y.-J.; Jang, S.-J.; Cheon, J.-W.; Lee, H.-S. Antioxidant and antiaging effect of ginseng berry extract fermented by lactic acid bacteria. J. Soc. Cosmet. Sci. Korea 2011, 37, 75-81.

15. Park, S.-J.; Kim, D.-H.; Paek, N.-S.; Kim, S.-S. Preparation and quality characteristics of the fermentation product of ginseng by lactic acid bacteria (FGL). J. Ginseng Res. 2006, 30, 88-94.

16. Gupta, S.; Abu-Ghannam, N. Probiotic fermentation of plant based products: Possibilities and opportunities. Crit. Rev. Food Sci. Nutr. 2012, 52, 183-199. [CrossRef]

17. Kim, S.; Lim, S. Functionality and research trend of probiotics. Food Ind. Nutr. 2018, 23, 18-24.

18. Kim, H.; Kim, J.-S.; Kim, Y.; Jeong, Y.; Kim, J.-E.; Paek, N.-S.; Kang, C.-H. Antioxidant and probiotic properties of Lactobacilli and Bifidobacteria of human origins. Biotechnol. Bioprocess. Eng. 2020, 25, 421-430. [CrossRef]

19. Abe, N.; Nemoto, A.; Tsuchiya, Y.; Hojo, H.; Hirota, A. Studies on the 1, 1-diphenyl-2-picrylhydrazyl radical scavenging mechanism for a 2-pyrone compound. Biosci. Biotechnol. Biochem. 2000, 64, 306-313. [CrossRef]

20. Ak, T.; Gülçin, İ. Antioxidant and radical scavenging properties of curcumin. Chem. Biol. Interact. 2008, 174, 27-37. [CrossRef]

21. Cheung, L.; Cheung, P.C.; Ooi, V.E. Antioxidant activity and total phenolics of edible mushroom extracts. Food Chem. 2003, 81, 249-255. [CrossRef]

22. Han, J.M.; Chung, H.-J. Quality characteristics of Yanggaeng added with blueberry powder. Korean J. Food Preserv. 2013, 20, 265-271. [CrossRef] 
23. Oyaizu, M. Antioxidative activities of browning reaction prepared from glucosamine. Jpn. J. Nutr. 1986, 44, 307-315. [CrossRef]

24. Reissig, J.L.; Strominger, J.L.; Leloir, L.F. A modified colorimetric method for the estimation of N-acetylamino sugars. J. Biol. Chem. 1955, 217, 959-966. [CrossRef]

25. Baumann, J. Prostaglandin synthetase inhibiting O_2-radical scavenging properties of some flavonoids and related phenolic compounds. Naunyn Schmiedebergs Arch. Pharmacol. 1979, 308, 27-32.

26. Kim, Y.-M.; Jeong, H.-J.; Chung, H.-S.; Seong, J.-H.; Kim, H.-S.; Kim, D.-S.; Lee, Y.-G. Anti-oxidative activity of the extracts from Houttuynia cordata Thunb. fermented by lactic acid bacteria. J. Life Sci. 2016, 26, 468-474. [CrossRef]

27. Song, B.N.; Lee, D.B.; Lee, S.H.; Park, B.R.; Choi, J.H.; Kim, Y.S.; Park, S.Y. Physicochemical properties and Antioxidant Activity of Extract from Astragalus membranaceus Bunge Leaf Fermented with Lactic Acid Bacteria. Korean J. Crop. Sci. 2020, 28, 428-434. [CrossRef]

28. Guideline, I.H.T. Validation of analytical procedures: Text and methodology. Q2 (R1) 2005, 1, 05.

29. Wang, F.; Zhao, S.; Li, F.; Zhang, B.; Qu, Y.; Sun, T.; Luo, T.; Li, D. Investigation of antioxidant interactions between Radix Astragali and Cimicifuga foetida and identification of synergistic antioxidant compounds. PLoS ONE 2014, 9, e87221. [CrossRef]

30. Ko, J.K.-S.; Lam, F.Y.-L.; Cheung, A.P.-L. Amelioration of experimental colitis by Astragalus membranaceus through anti-oxidation and inhibition of adhesion molecule synthesis. World J. Gastroenterol. 2005, 11, 5787. [CrossRef]

31. Ma, R.; Yuan, F.; Wang, S.; Liu, Y.; Fan, T.; Wang, F. Calycosin alleviates cerulein-induced acute pancreatitis by inhibiting the inflammatory response and oxidative stress via the p38 MAPK and NF-kB signal pathways in mice. Biomed. Pharmacother. 2018, 105, 599-605. [CrossRef]

32. MacMicking, J.; Xie, Q.-W.; Nathan, C. Nitric oxide and macrophage function. Annu. Rev. Immunol. 1997, 15, 323-350. [CrossRef] [PubMed]

33. Nathan, C.; Xie, Q.-W. Nitric oxide synthases: Roles, tolls, and controls. Cell 1994, 78, 915-918. [CrossRef]

34. Wink, D.A.; Miranda, K.M.; Espey, M.G.; Pluta, R.M.; Hewett, S.J.; Colton, C.; Vitek, M.; Feelisch, M.; Grisham, M.B. Mechanisms of the antioxidant effects of nitric oxide. Antioxid. Redox Signal. 2001, 3, 203-213. [CrossRef] [PubMed]

35. Gong, G.; Zheng, Y.; Yang, Y.; Sui, Y.; Wen, Z. Pharmaceutical Values of Calycosin: One Type of Flavonoid Isolated from Astragalus. Evid.-Based Complementary Altern. Med. 2021, 2021, 9952578. [CrossRef] [PubMed]

36. Hu, T.; Liu, Q.-M.; He, X.-W.; Huang, F.; Zhang, M.-W.; Jiang, J.-G. Identification of bioactives from Astragalus chinensis Lf and their antioxidant, anti-inflammatory and anti-proliferative effects. J. Food Sci. Technol. 2017, 54, 4315-4323. [CrossRef] [PubMed]

37. Delgado, A.V.; McManus, A.T.; Chambers, J.P. Production of tumor necrosis factor-alpha, interleukin 1-beta, interleukin 2, and interleukin 6 by rat leukocyte subpopulations after exposure to substance P. Neuropeptides 2003, 37, 355-361. [CrossRef] [PubMed]

38. Park, H. Anti-Oxidant and Anti-Inflammation Activity of the Fermented Astragalus membranaceus Extract by Lactiplantibacillus plantarum. Master's Thesis, Semyung University, Jecheon-si, Chungcheongbuk-do, Korea, 2021. 